\title{
A Contrastive Study of the Connotative Meaning of Linguistic Signs in English and Chinese
}

\author{
Yanchun Zhou \\ Changchun University of Science and Technology, Changchun, China \\ Email: zyczyh@yahoo.com.cn
}

\begin{abstract}
According to G. Leech's classification of meaning, the denotative meaning of a word is different from its connotative one. The denotation of a linguistic sign may be the same in different languages, but their connotations may be quite different. The paper makes a contrastive analysis of the connotative meaning of linguistic signs in English and Chinese, such as Color terms, Kinship terms, Animal-related Words and Euphemisms. It also discusses the reason for the differences between the two languages.
\end{abstract}

Index Terms - connotative meaning, color terms, kinship terms, animal-related words, euphemisms, English and Chinese

\section{INTRODUCTION}

Some linguists believe any linguistic sign may be simultaneously of a denotative, connotative, or iconic kind of meanings. Any sign has a meaning that can be found in a dictionary, which is the basic meaning or central meaning of it. This is the denotative meaning. For example, bird is a creature with feathers and wings, usually able to fly, lay eggs and build nests. In most cases, bird means more than a creature. To be as free as a bird is to feel completely free. We can easily associate a bird with freedom. It is the connotative meaning, which refers to emotional associations that a word suggests in one's mind. A linguistic sign can also stir up imagination in one's mind. The word bird invokes image to people, that is, something in one's imagination, such as dove, eagle etc. This is the iconic meaning.

The British linguist G. Leech (1974) recognizes 7 types of meaning in his Semantics, as follows: denotative meaning, connotative meaning, social meaning, affective meaning, reflected meaning, collocative meaning and thematic meaning. Leech (1974) says that the first type of meaning makes up the central part. It is "denotative" in that it is concerned with the relationship between a word and the thing it denotes, or refers to. "Connotative" refers to some additional, especially emotive meaning. The difference between politician and statesman, for example, is connotative in that the former is derogatory while the latter is commendatory.

It is easy to understand that the same word in different languages may be entailed with different connotations. Connotations means "the implication of a word, apart from its primary meaning", according to the Longman Modern English Dictionary, or "the suggesting of meaning by a word apart from the thing it explicitly names or describes", according to the Webster (Dai \& He, 2010, p.134). Therefore the denotation of a word, its dictionary meaning, is different from its connotation. Sometimes, the denotative meaning of a linguistic sign may be the same in two languages, but their connotations may be quite different. The paper analyzes the connotative meaning of the following linguistic signs in English and Chinese: Color terms, Kinship terms, Animal-related Words and Euphemisms. They are the typical examples of the cultural-specific connotations in language use.

\section{The Connotative MeAning of COLOR Terms}

Color word systems in different languages are culturally determined, and hence different from one another. Basic color terms vary from 2 to 11 in number. English has 11 basic color terms - white, black, red, green, yellow, blue, brown, purple, pink, orange and gray. Chinese has 12. There may be 2, 3 or 6 color terms in some cultures. For example, Danti has 2 basic color words: modla and mili. The contrast between modla and mili in fact is a contrast between "whitewarmness" versus "blackcoldness" (Hu, 2006). Different languages entail different color related associations. That is, color terms have traditional connotative meaning apart from their denotative meaning.

If you are not familiar with the connotative meaning of green in English, you can hardly understand the following utterance Do you see any green in her eye? In English, green symbolizes youth. It is related to something imperfect or immature, and somebody inexperienced or naive, as shown in a green thought(一个不成熟的想法). We can translate it into Chinese like this 你以为她幼稚可欺吗? In English, green is also associated with jealousy or envy, such as green-eyed(眼红).From Tang Poetry in Chinese, we can infer that we Chinese always connect green with the spring. In our minds, green symbolizes life and force. Considering the following poems, “最爱湖天行不足, 绿阳阴里白沙堤。” (白居易《钱塘湖春行》) ; “春草年年绿, 王孙归不归。” (王维《送别》); “燕草如碧丝, 秦桑低绿枝。” (李 白《春思》); “千里莺啼绿映红，水村山郭酒旗风。”（杜牧《江南春》）... 
Other example, red is related to celebration and happy events in both western and Chinese cultures. However, in English sometimes red is the symbol of danger and urgency. The British often associate red with blood and the dead. But in a traditional sense, Chinese tend to associate red with good luck or beautiful scenery as follows: “去年今日此门 中, 人面桃花相映红。” (崔护《题都城南庄》); “一道残阳铺水中，半江瑟瑟半江红。” (白居易《暮江吟》); “草树知春不久归，百般红紫斗芳菲。”（韩愈《晚春》）. In Chinese, white is related to something unfortunate. In western culture, white symbolizes purity. Blue suggests sentimental or unhappy feelings in He is in a blue mood.. Meanwhile blue is also associated with high social position or being aristocratic as in He is a real blue blood. Another example is that people call a book with well-known names blue book in America. In Chinese, 蓝色 doesn't have the corresponding connotative meaning.

\section{The Connotative Meaning of Kinship Terms}

Kinship terms in different languages have different cultural connotations. Kinship terms are more highly codable in Chinese than they are in English. In Chinese there are 2 sets of terms distinguishing relatives on the father's side(伯伯, 叔叔, 姑父, 伯母, 婶婶, 姑姑) and those on the mother's side（舅舅, 姨夫, 舅妈, 姨妈).For native speakers of Chinese, these terms allow a clear distinction of the relation. In contrast, there are no exactly equivalent terms in English. Kinship terms in different languages reflect different ways to categorize blood and marriage relations. For instance, the denotative meaning of aunt in English is as follows - the sister of someone's father or mother, or the wife of someone's uncle. The term aunt can be used to address many relatives in English. But their connotative meanings are the same, that is, to address female relatives of similar position in family. Native English speakers do not see the distinction between one's father's sister and one's mother's sister as significant. Chinese attach more importance to blood relations and the surname. Most Chinese are close to relatives on father's side. The connotative meanings of 姑 姑(one's father's sister ), 姨妈(one's mother's sister), 伯母/婶婶’舅妈(the wife of one's uncle) in Chinese are quite different. 姑姑 is the closest to us, because we share the same surname. 姨妈 is closer to us than 伯母/婶婶/舅妈 because of blood relations.

The extension of kinship terms is another feature of Chinese culture. Terms such as uncle, aunt, grandpa and granny are used as honorific titles for senior people or strangers, as in Granny Li and Uncle Zhang. Native English speakers would be puzzled if they are addressed in this way by people outside the immediate family.

\section{The Connotative Meaning OF Animal-RELATEd WordS}

If we make a comparison between English and Chinese, we may easily get some words related to animals in both languages. Animals have distinctive images. Many Animal-related words are beyond their original meaning. They are endowed with different mental implications in the two languages. Animal-related words seem to correspond in denotative meaning, but may considerably vary in connotative meaning or emotional meaning.

In western culture, the lion is regarded as the king of the beasts. Apart from the denotative meaning - beasts, the lion has the following connotative meanings. Someone who is lion-hearted is very brave. A lion also refers to someone who is important or successful. For example, He is one of the young jazz lions on the New York music scene (他是纽约音乐 圈年轻的爵士乐明星之一). The sight of a lion fills people with awe, as shown in the idioms regal as a lion (狮子一般 威严), majestic as a lion(像狮子一样雄伟).A lion's den is a dangerous or threatening place. While Chinese only focus on the denotative meaning of the lion-beasts. Instead of the lion, 虎(the tiger) is endowed with the similar emotional meaning by Chinese. So we have idioms such as 虎胆英雄, 狐假虎威, 虎视睄睄, 虎踞龙蟠, 虎口余生... The Chinese version of A lion in the way is 拦路虎. In English, Owls are often considered to be wise. This connotative meaning of an owl is different from that of Chinese. Because owls usually go out at night crying sadly, Chinese easily associate owls with the dead or something unfortunate.

What are the reasons for the different understanding of animal images? We will consider a lot. Because of different customs, habits, beliefs, attitudes and taboos, westerners and Chinese have different ways of thinking. The same phenomenon may be described by different animals in different languages. This is the change of animal images, as shown in as strong as a horse (气壮如牛), talk horse(吹牛), work like a horse(像老黄牛一样干活), a horse of another color(风马牛不相及的事). Due to different historical and cultural background, the Chinese version is not correspondent to the English form. Of all ages, a cattle has been used to plough the field by Chinese. Out of habit, British farmers used the horse instead in ancient times. Similarly, like a rat in the hole (㸗中捉鳖), two dogs strive for a bone and a bird runs away with it (柕蚌相争, 鱼翁得利) etc. The understanding of animal images varies from culture to culture.

\section{The Connotative Meaning OF Euphemisms}

Euphemisms tell us a good deal about the values of a culture, for words in sensitive areas tend to pick up negative connotations and to be replaced by euphemisms. Euphemisms can be classified into 2 types-positive and negative, in 
terms of Semantics. Positive euphemisms can make things substituted more honorable by hyperbole. Floor-sweeper is titled custodian engineer in English. 环卫工人 is replaced by 城市的美容师 in Chinese. From the above terms, we can infer social attitudes towards humble jobs. In both cultures, the public tend to show respect for those of a low social status.

The connotation of negative euphemisms is to decrease the depressing influence exerted by taboos. It is the substitution of an inoffensive expression for an offensive one. What is a taboo in English may not be so in Chinese. As a result, Euphemisms have cultural-specific connotations. The term drunk is a taboo in English, replaced by intoxicated. Similarly drunkenness is replaced by alcohol problem, for instance, He has an alcohol problem (某人醉着行路). In Chinese, the character 醉 is not a taboo. From Tang Poetry, we can infer 醉 is related to something romantic or satisfied, for example, “钟鼓馔玉何足贵, 但愿长醉不愿醒。” (李白《将进酒》); “巴陵无限酒, 醉杀洞庭秋。” (李白《陪侍郎叔游洞庭醉后》); “醉卧沙场君笑, 古来征战几人回。”(王翰《凉州词》).

In English, people in poverty are not titled the poor, because the word poor is a taboo. Poor can be replaced by many euphemisms. As some unfortunate person put it: "At first I was poor, then I became needy, later I was underprivileged. Now I'm disadvantaged. I still don't have a cent to my name, but I sure have a great vocabulary." From this example, we can see some inoffensive expressions replace poor, such as needy(生活艰苦的), underprivileged (下层社会的), disadvantaged(被剥夺了基本权利的). The above euphemisms have cultural-specific connotations. In recent years, people from western culture strive for equal opportunity. They are against various social discriminations. Some euphemisms related to equality occur. People in Hunan, China say 富菜 instead of 芹菜.Because of regional dialect, the pronunciation of 芹 and 穷 are the same there. It is human psychology to fear poverty. Poor refers to a struggle to survive. Chinese say 条件不成熟 instead of 穷, 手头紧 instead of 没钱. Euphemisms are closely related to social culture, which have specific connotative meanings.

\section{CONCLUSION}

The connotative meaning of linguistic signs refers to the emotional association which a sign suggests in addition to its explicit denotative meaning. Color terms have traditional connotative meaning apart from their denotative meaning. English and Chinese entail different color related associations. In Chinese there are 2 sets of Kinship terms distinguishing relatives on the father's side and those on the mother's side. In contrast, there are no exactly equivalent terms in English. Kinship terms in different languages reflect different ways to categorize blood and marriage relations. Animals have distinctive images. Many Animal-related words are beyond their original meaning. They are endowed with different mental implications or connotative meaning in the two languages because of historical and cultural background. The connotation of negative euphemisms is to decrease the depressing influence exerted by taboos. What is a taboo in English may not be so in Chinese. Because of anti-discrimination or human psychology, Euphemisms have cultural-specific connotations.

\section{REFERENCES}

[1] Claire Kramsch. (2000). Language and Culture. Shanghai: Shanghai Foreign Language Education Press.

[2] Dai Weidong \& He Zhaoxiong. (2010). A New Concise Course in Linguistics for Students of English (2nd edn.). Shanghai: Shanghai Foreign Language Education Press.

[3] Deng Yanchang \& Liu Runqing. (2001). Language and Culture. Beijing: Foreign Language Teaching and Research Press.

[4] Hu Zhuanglin. (2006). Linguistics: A Course Book (3rd edn.). Beijing: Beijing University Press.

[5] Leech, G. (1974/1981). Semantics: The Study of Meaning (2nd edn.). Harmondsworth: Penguin.

[6] Widdowson, H.G. (1996). Linguistics. Oxford: Oxford University Press.

Yanchun Zhou was born in Panshi, Jilin Province, China on March 15 th, 1978, who has got a degree of Master of Arts in foreign linguistics and applied linguistics from Changchun University of Science and Technology, Changchun, Jilin Province, China in 2003.

As a LECTURER, she teaches Foreign Linguistics of the English major at School of Foreign Languages, Changchun University of Science and Technology. One book (as an editor) and two published articles are as follows: [1] College English Test-Writing.(Changchun, Jilin Province: Foreign Language Education's Books, Jilin Publishing Group, 2009); [2] A Study of Gender differences in English and Chinese (Changchun, Jilin Province: Writer Magazine, 2010); [3] From Wilderness of American Literature to Its Environmental Awareness (Taiyuan, Shanxi Province: Masterpieces Review, 2011). Previous research interests are Linguistics and Semantics. At present she focuses on Pragmatics \& Cognitive Linguistics. 